\title{
PENGARUH MODEL PEMBELAJARAN DAN MOTIVASI INTRINSIK TERHADAP HASIL BELAJAR KETERAMPILAN MEMBACA BAHASA ARAB SISWA
}

\author{
Vina Susanti ${ }^{1}$, Harun Sitompul ${ }^{2}$, Hamonangan Tambunan ${ }^{3}$ \\ ${ }^{1}$ Sekolah Menengah Pertama Plus Darul Ilmi Murni Deli Serdang Sumatera Utara, \\ ${ }^{2,3}$ Program Pascasarjana Universitas Negeri Medan \\ Ivinasusanti@gmail.com, ${ }^{2}$ prof_runsit@yahoo.co.id, ${ }^{3}$ hamtambun@gmail.com
}

\begin{abstract}
Abstrak: Penelitian ini bertujuan (1) untuk mengetahui hasil belajar keterampilan membaca bahasa Arab siswa yang diajar dengan menggunakan model pembelajaran mind mapping lebih tinggi daripada siswa yang diajar dengan menggunakan model pembelajaran langsung, (2) untuk mengetahui hasil belajar keterampilan membaca bahasa Arab siswa yang memiliki motivasi intrinsik tinggi lebih tinggi daripada siswa yang memiliki motivasi intrinsik rendah, (3) untuk mengetahui interaksi antara model pembelajaran dengan motivasi intrinsik terhadap hasil belajar keterampilan membaca bahasa Arab. Penelitian ini merupakan penelitian quasi eksperimen dengan desain penelitian faktorial $2 \times 2$. Teknik analisis data menggunakan ANAVA dua jalur pada taraf signifikan $\propto=0,05$. Temuan penelitian menunjukkan bahwa; (1) hasil belajar keterampilan membaca bahasa Arab siswa yang diajar dengan model pembelajaran mind mapping lebih tinggi dari hasil belajar siswa yang diajar dengan model pembelajaran langsung dengan $\mathrm{F}_{\text {hitung }}=6,08$ $>\mathrm{F}_{\text {tabel }}=3,97$, (2) hasil belajar keterampilan membaca bahasa Arab siswa yang memiliki motivasi intrinsik tinggi lebih tinggi dari siswa yang memiliki motivasi intrinsik rendah dengan $\mathrm{F}_{\text {hitung }}=60,34>\mathrm{F}_{\text {tabel }}=3,97$, (3) terdapat interaksi antara model pembelajaran dan motivasi intrinsik terhadap hasil belajar keterampilan membaca bahasa Arab, dengan $\mathrm{F}_{\text {hitung }}=28,92$ > $\mathrm{F}_{\text {tabel }}=3,97$.
\end{abstract}

Kata Kunci: model pembelajaran, motivasi intrinsic, keterampilan membaca bahasa arab

Abstract: This study aims (1) to determine the learning outcomes of Arabic reading skills students who are taught using mind mapping learning models are higher than students who are taught using direct learning models, (2) to find out the learning outcomes of Arabic reading skills students who have higher intrinsic motivation than students who have low intrinsic motivation, (3) to find out the interaction between learning models and intrinsic motivation on the learning outcomes of Arabic reading skills. This research is a quasi-experimental research with $2 \times 2$ factorial research design. Data analysis techniques using two-way ANAVA at a significant level $=0.05$. Research findings indicate that; (1) the learning outcomes of Arabic reading skills students taught with mind mapping learning models are higher than the learning outcomes of students taught with direct learning models with $F_{\text {count }}=6.08>F_{\text {table }}=3.97$, (2) learning outcomes of students' Arabic reading skills those who have high intrinsic motivation are higher than students who have low intrinsic motivation with $F_{\text {count }}=60.34>F_{\text {table }}=3.97$, (3) there is an interaction between the learning model and intrinsic motivation towards the learning outcomes of Arabic reading skills, with $F$ count $=28.92>F_{\text {table }}=3.97$.

Keywords: learning model, intrinsic motivation, Arabic reading skills

\section{PENDAHULUAN}

Mata pelajaran bahasa Arab merupakan mata pelajaran muatan lokal yang menjadi salah satu nilai plus pada SMP Plus Darul Ilmi Murni Deli Serdang, karena SMP
Plus Darul Ilmi Murni merupakan sekolah berbasis Islam yang lebih mengunggulkan pelajaran Agama, dan pelajaran bahasa Arab merupakan pelajaran unggulan yang menjadi inti dalam memahami mata pelajaran Agama 
lainnya yaitu Pendidikan Agama Islam, AlQur'an, dan Akhlak.

Namun, meskipun bahasa Arab sudah masuk dalam mata pelajaran tersendiri di sekolah-sekolah, tidak semudah membalikkan telapak tangan siswa dapat menyerap, memahami, serta menguasai materi bahasa Arab yang telah diajarkan. Banyak siswa yang merasa kesulitan dalam membaca untuk menyerap dan memahami, apalagi menguasai materi bahasa Arab yang telah diajarkan oleh gurunya. Bahkan banyak di antara mereka yang menganggap pelajaran bahasa Arab sebagai momok yang menakutkan karena terlalu dibebani dengan sederet hafalan-hafalan dan membaca teks berbahasa Arab. Jadi yang dipermasalahkan sekarang adalah bagaimana meningkatkan kualitas keterampilan membaca bahasa Arab yang masih dianggap oleh siswa sebagai bahasa yang sulit untuk dipelajari. Hal ini merupakan tantangan yang segera harus diupayakan pemecahannya. Berbagai upaya telah dilakukan untuk meningkatkan keterampilan membaca bahasa Arab seperti pengadaan pusat latihan, pengadaan laboratorium bahasa, kursus-kursus, media massa yang menyajikan bahasa Arab.

Selanjutnya Yusuf dan Anwar (1995) menjelaskan bahwa bahasa Arab yang sebenarnya tidaklah sulit, asalkan tekun dan rutin (bersungguh-sungguh dan serius) serta berani mempraktekkannya, tidak perlu malu/takut salah serta banyak latihan. Hal itu dapat dilakukan baik di madrasah maupun luar madrasah, sehingga bahasa Arab bukan lagi hal yang ditakuti dan dianggap sukar oleh siswa.

Kenyataan yang dihadapi bahwa keterampilan membaca bahasa Arab siswa cukup rendah. Hal ini ditandai dengan belum maksimalnya hasil belajar bahasa Arab yang diperoleh siswa. Sebagai contoh adalah di kelas VII SMP Plus Darul Ilmi Murni Deli Serdang bahwa hasil belajar kemampuan membaca bahasa Arab siswa belumlah memuaskan. Berdasarkan Tabel 1 berikut ini akan dijelaskan nilai rata-rata Ujian Akhir Semester bahasa Arab siswa kelas VII SMP Plus Darul Ilmi Murni.

\section{Model Pembelajaran Mind Mapping}

Menurut Windura (2008), model pembelajaran Mind Mapping tidak terlepas dari kemampuan otak manusia yang tidak terbatas, tidak ada otak yang lebih baik dari pada otak manusia. Otak yang tersimulasi mempunyai jaringan otak lebih banyak. Banyaknya jaringan ini akan menentukan kecerdasan dan kreativitas anak.

Pangkalan Ide (2009), mengemukakan bahwa manusia baru menggunakan potensi dan kapasitas otaknya kurang dari $1 \%$ saja, begitu pula dengan siswa. Otak kiri disebut juga otak analisis, sedangkan otak kanan sering disebut dengan otak kreatif. Manusia semua umumnya lebih sering menggunakan sisi otak kiri karena lingkungan dimana manusia hidup menuntut demikian.

Mind Mapping pertama kali ditemuan oleh Tony Buzan (1971), pemikiran awal ini ditemukan saat melihat komputer pada tahun 1971, dimana komputer yang lengkap dengan sebuah panduan/petunjuk mengenai bagaimana menggunakan komputer. Kemudian Buzan heran mengapa otak manusia yang jauh lebih istimewa tidak disertai manual penggunaan ? Maka untuk pertama kalinya ia ciptakanlah mind mapping sebagai cara untuk dapat memaksimalkan kemampuan otak. Buzan menekankan penggunaan mind mapping sebagai alat untuk melatih orang berpikir dengan lebih berdaya guna untuk meningkatkan kemampuan belajar dan pengelolaan proyek.

Mind mapping merupakan suatu terobosan baru untuk dapat mengelompokkan beberapa masalah sehingga dapat mengaitkannya satu dengan lainnya. Hal ini hampir sama seperti diagram ikan atau lebih banyak dikenal sebagai Flash Bone Diagram. Mind Mapping akan sangat memaksimalkan kemampuan otak dalam melakukan analisis. Berbeda dengan komputer yang bekerja dalam siklus yang linear, seorang ketua yayasan otak, pendiri klub pakar (Brain Trust) dan pencipta konsep melek mental. Otak merupakan asosiasi dari kombinasi linear dengan kemampuan integrasi, komparasi dan sintesis.

Prinsip Mind Mapping sangatlah sederhana, cukup mengikuti kemana otak kita berpikir, apa yang terlintas, apa yang teringat, dan tuliskan di atas kertas dalam bentuk coretan yang berkait-kaitan. Coretan tersebut dimulai dari tengah kertas sebagai pusat, kemudian mengembang keluar ke arah tepi kertas. Ini merupakan konsep radiant thinking.

Model Mind Mapping adalah salah satu model pembelajaran yang dapat mensinergikan dan mengaktifkan otak kiri dan otak kanan. Mind Mapping adalah suatu teknis grafis yang memungkinkan siswa untuk mengeksplorasi seluruh kemampuan otak siswa 
untuk keperluan berpikir dan belajar (DePorter, 2002). Mind Mapping menggunakan banyak gambar, warna-warna, dan ilustrasi sehingga mengaktifkan otak kanan dan menyeimbangkan otak kiri, sehingga anak belajar dengan menyenangkan.

\section{Model Pembelajaran Langsung (Directive Instruction)}

Model pembelajaran directive umumnya berorientasi pada kegiatan yang berpusat pada guru (teacher oriented). Model Pengajaran langsung (Direct Intruction) merupakan suatu pendekatan mengajar yang dapat membantu siswa dalam mempelajari keterampilan dasar dan memperoleh informasi yang dapat diajarkan selangkah demi selangkah. Ausubel (1986) membedakan belajar menerima dengan belajar menemukan. Pada belajar menerima bentuk akhir dari yang diajarkan itu diberikan sedangkan belajar menemukan, bentuk akhir itu harus dicari siswa. Ausubel (1986) juga membedakan antara belajar menghafal dengan belajar bermakna. Belajar menghafal, siswa belajar melalui menghafal apa yang sudah diperoleh. Belajar bermakna adalah belajar yang untuk memahami apa yang sudah diperolehnya itu dikaitkan dengan keadaan lain sehingga belajarnya itu lebih bermakna.

Menurut Arends (1997), model pembelajaran langsung adalah salah satu pendekatan mengajar yang dirancang khusus untuk menunjang proses belajar siswa yang berkaitan dengan pengetahuan deklaratif dan pengetahuan prosedural yang terstruktur dengan baik yang dapat diajarkan dengan pola kegiatan yang bertahap, selangkah demi selangkah. Menurut Roy Killen (1998), direct instruction merujuk pada berbagai teknik pembelajaran ekspositori (pemindahan pengetahuan dari guru kepada murid secara langsung, misalnya melalui ceramah, demonstrasi, dan tanya jawab) yang melibatkan seluruh kelas. Pendekatan dalam model pembelajaran ini berpusat pada guru di mana guru menyampaikan isi akademik dalam format yang sangat terstruktur, mengarahkan kegiatan para siswa, dan mempertahankan fokus pencapaian akademik.

Selanjutnya menurut Kardi (2000), model pembelajaran langsung merupakan model pembelajaran yang berbentuk ceramah, demonstrasi, pelatihan atau praktik, dan kerja kelompok. Pengajaran langsung digunakan untuk menyampaikan pelajaran yang ditrasformasikan langsung oleh guru kepada siswa. Penyusunan waktu yang digunakan untuk mencapai tujuan pembelajaran harus seefisien mungkin, sehingga guru dapat merancang dengan tepat waktu yang digunakan. Pada umumnya metode yang digunakan dalam model pembelajaran ini berlangsung satu arah, pengajar memberikan ide atau informasi dan siswa menerimanya. Model pembelajaran langsung menghendaki siswa dapat menangkap dan mengingat informasi yang telah diberikan guru, serta mengungkapkan kembali apa yang dimilikinya menjadi respon yang ia berikan pada saat guru melontarkan pertanyaan. Kemampuan yang diharapkan seorang guru pada siswa sebagai hasil belajar dengan strategi langsung dapat memahami apa yang diterangkan guru, mampu mengingat bahan yang disajikan, menerima tugas tanpa menolak, mendapat hasil ujian baik, serta selalu bekerja rapi dan teratur.

\section{Hakikat Motivasi Intrinsik}

Motivasi dapat merupakan tenaga pendorong atau penarik yang menyebabkan adanya tingkah laku ke arah suatu tujuan tertentu. Secara psikologis menurut Hebb (1960) bahwa motivasi didefenisikan sebagai daya pendorong yang menyebabkan orang bertindak untuk melangkah kepada sesuatu yang ditentukan.

McClelland (1975) mendefenisikan motivasi sebagai "the reintegration by cue of a change in affective situation" tiga istilah penting yang perlu dijelaskan dalam defenisi ini adalah : reintegration, cue dan affective situation. Istilah reintegration secara etimologis berarti membulatkan kembali atau membuat suatu kesatuan yang baru. Dalam konteks ini reintegration berarti membulatkan kembali proses psikologis dalam kesadaran sebagai akibat adanya rangsangan suatu peristiwa dalam lingkungan. Sebagai contoh, seseorang mendengar beberapa nada sebuah lagu yang sudah dikuasainya, maka keseluruhan persepsi tentang lagu itu timbul kembali, sekalipun tidak akan sama dengan persepsi yang lama. Cue (isyarat) merupakan penyebab tergugahnya afeksi dalam diri individu.

Maslow (1983) dalam teori kebutuhannya menjelaskan bahwa kebutuhan seseorang tergantung apa yang telah dipunyai dan apa yang merupakan keinginannya. Kebutuhan-kebutuhan tersebut bila ditinjau dari posisinya merupakan jenjang atau tingkatan kebutuhan fisiologis, kebutuhan rasa aman, 
kebutuhan akan cinta, dan diterima dalam kelompok, kebutuhan akan harga diri, serta kebutuhan aktualisasi diri. Instensitas kebutuhan tersebut tergantung pada posisi jenjang kebutuhan serta diawali pemenuhan kebutuhan yang lebih rendah tingkatannya.

Dari berbagai pengertian motivasi yang telah dikemukakan di atas, dapat disimpulkan bahwa motivasi adalah suatu dorongan (tenaga) atau faktor yang dapat mempengaruhi, menimbulkan, mengarahkan dan mengorganisasikan tingkah laku manusia dalam memenuhi tujuan yang dikehendaki.

Hamzah B. Uno (2006) menyatakan bahwa motivasi dibedakan menjadi dua bagian, yaitu : motivasi intrinsik dan motivasi ekstrinsik. Hal yang sama diungkapkan Petri (1981) bahwa hasrat ingin tahu merupakan aspek penting yang dimotivasi secara intrinsik. Motivasi intrinsik berdasarkan sumbernya datang dalam diri orang yang bersangkutan dan motivasi ekstrinsik apabila sumbernya adalah lingkungan di luar diri orang yang bersangkutan. Dari berbagai pengertian, pandangan, konsep teori dan sumber motivasi yang telah diuraikan, penulis menyimpulkan bahwa motivasi dapat dikelompokkan kedalam dua jenis motivasi, yaitu : (1) motivasi intrinsik, dan (2) motivasi ekstrinsik. Motivasi intrinsik, motivasi yang datang dari dalam diri orang yang bersangkutan. Sedangkan motivasi ekstrinsik adalah dorongan untuk berbuat lebih disebabkan karena pengaruh dari luar, seperti dari lingkungan atau dari orang lain.

Berdasarkan latar belakang, identifikasi dan pembatasan masalah di atas, maka masalah pada penelitian ini dapat dirumuskan sebagai berikut:

1. Apakah hasil belajar keterampilan membaca bahasa Arab siswa yang diajar dengan model pembelajaran Mind Mapping lebih tinggi dari hasil belajar bahasa Arab siswa yang diajar dengan model pembelajaran langsung ?

2. Apakah hasil belajar keterampilan membaca bahasa Arab siswa yang mempunyai motivasi intrinsik tinggi lebih tinggi dari hasil belajar bahasa Arab siswa yang mempunyai motivasi intrinsik rendah ?

3. Apakah terdapat interaksi antara model pembelajaran dan motivasi intrinsik terhadap hasil belajar keterampilan membaca bahasa Arab siswa?

\section{METODE}

Penellitian ini dilaksanakan di kelas VII SMP Plus Darul Ilmi Murni Deli Serdang Jl. Besar Namorambe Kecamatan Deli Tua Kabupaten Deli Serdang. Populasi dan sampel dalam penelitian ini adalah seluruh siswa kelas VII yang terdiri dari 4 (empat) kelas yaitu kelas VII A, VII B, VII C,dan VII D dengan jumlah keseluruhan siswa adalah 140 orang. Setiap kelas memilki karakteristik yang sama, artinya setiap kelas tidak memiliki siswa yang pernah tinggal kelas, siswa rata-rata memiliki umur yang tidak jauh berbeda dan menggunakan kurikulum yang sama. Pembagian kelas tidak berdasarkan rangking, sehingga kelas-kelas tersebut dapat dikatakan kelas heterogen. Penarikan sampel dilakukan secara acak melalui undian, sehingga dari 4 (empat) kelas diperoleh 2 (dua) kelas perlakuan. Teknik pengambilan sampel dilakukan dengan teknik cluster random sampling, dari dua kelas yang terpilih sebagai sampel penelitian. Dari hasil pengundian, terpilih dua kelas sebagai kelas eksperimen yaitu kelas VII A dan kelas VII B. Kelas VII A merupakan kelas yang ditempatkan sebagai kelas yang diberi perlakuan dengan model pembelajaran Mind Mapping berjumlah 40 siswa dan kelas VII B yang diberi pelakuan dengan model pembelajaran langsung yang berjumlah 40 siswa. Sehingga jumlah sampel dalam penelitian sebanyak dua kelas yang terdiri dari 80 siswa.

Dalam penelitian ini metode yang akan digunakan adalah metode eksperimental semu (quasi-experimental research) dengan desain faktorial $2 \times 2$. Melalui desain ini akan dibandingkan pengaruh model pembelajaran Mind Mapping dan lansung terhadap hasil belajar keterampilan membaca bahasa Arab ditinjau dari motivasi intrinsik siswa. Model pembelajaran Mind Mapping dan langsung diperlakukan kepada kelompok eksperimen siswa dengan motivasi intrinsik siswa yang berbeda. Model pembelajaran Mind Mapping dan langsung sebagai variabel bebas, perbedaan motivasi intrinsik sebagai variabel moderator dan perolehan hasil belajar keterampilan membaca dalam mata pelajaran bahasa Arab sebagai variabel terikat. Variabel-variabel tersebut akan dimasukkan di dalam desain penelitian seperti pada Tabel 1 sebagai berikut : 
Tabel 1. Desain Penelitian Anava Dua Jalur dengan Faktorial 2x2

\begin{tabular}{ccc}
\hline Motivasi & \multicolumn{2}{c}{ Model Pembelajaran (A) } \\
\cline { 2 - 3 } Intrinsik (B) & $\begin{array}{c}\text { Mind } \\
\text { Mapping } \\
\left(A_{1}\right)\end{array}$ & $\begin{array}{c}\text { Langsung } \\
\left(A_{2}\right)\end{array}$ \\
\hline Tinggi $\left(B_{1}\right)$ & $A_{1} B_{1}$ & $A_{2} B_{1}$ \\
\hline $\begin{array}{c}\text { Rendah } \\
\left(B_{2}\right)\end{array}$ & $A_{1} B_{2}$ & $A_{2} B_{2}$ \\
\hline
\end{tabular}

Keterangan :
$\mathrm{A}=$ Model Pembelajaran
$\mathrm{B}=$ Motivasi Intrisik
$A_{1}=$ Model pembelajaran Mind Mapping
$A_{2}=$ Model Pembelajaran Langsung
$B_{1}=$ Motivasi intrinsik tinggi
$B_{2}=$ Motivasi intrinsik rendah

$A_{1} B_{1}=$ Hasil Belajar Keterampilan MembacaBahasa Arab siswa yang diajar dengan model pembelajaran Mind Mapping pada siswa yang memiliki motivasi intrinsik tinggi

$A_{1} B_{2}=$ Hasil Belajar Keterampilan Membaca

Bahasa Arab siswa yang diajar dengan model pembelajaran Mind Mapping pada siswa yang memiliki motivasi intrinsik rendah

$A_{2} B_{1}=$ Hasil Belajar Bahasa Keterampilan membaca Arab siswa yang diajar dengan model pembelajaran langsung pada siswa yang memiliki motivasi intrinsik tinggi

$A_{2} B_{2}=$ Hasil Belajar Keterampilan Membaca Bahasa Arab siswa yang diajar dengan model pembelajaran langsung pada siswa yang memiliki motivasi intrinsik rendah

Penelitian ini menggunakan teknik analisis data berupa analisis deskriptif dan analisis inferensial. Teknik analisis deskriptif dimaksudkan untuk mendeskripsikan data penelitian meliputi rata-rata (mean), median, modus, varians dan simpangan baku. Data-data yang telah diperoleh selanjutnya disajikan dalam bentuk tabel distribusi frekuensi dan histogram kecenderungan data. Teknik analisis inferensial digunakan untuk menguji hipotesis penelitian dengan menggunakan teknik analisis varians (ANAVA) dua jalur. Sudjana (2002) menjelaskan sebelum ANAVA dua jalur dilakukan, terlebih dahulu ditentukan persyaratan analisis yakni persyaratan normalitas menggunakan uji Liliefors, sedangkan untuk uji persyaratan homogenitas menggunakan uji Fisher dan uji Barlet. Setelah melakukan pengujian persyaratan analisis, selanjutnya dilakukan pengujian ANAVA dua jalur, jika ternyata hasil hipotesis penelitian menyatakan ada interaksi selanjutnya dilakukan uji lanjut dengan menggunakan uji Tuckey dengan jumlah sampel setiap sel sama.

\section{Hipotesis Statistik}

Untuk keperluan pengujian hipotesis, dirumuskan hipotesis statistik sebagai berikut:

a. Hipotesis pertama:

$$
\begin{aligned}
& H_{o}: \mu_{A 1}=\mu_{A 2} \\
& H_{a}: \mu_{A 1}>\mu_{A 2}
\end{aligned}
$$

b. Hipotesis kedua:

$$
\begin{aligned}
& H_{o}: \mu_{B 1}=\mu_{B 2} \\
& H_{a}: \mu_{B 1}>\mu_{B 2}
\end{aligned}
$$

c. Hipotesis ketiga:

$$
\begin{aligned}
& H_{o}: A x B=0 \\
& H_{a}: A x B \neq 0
\end{aligned}
$$

Keterangan:

$\mu_{A 1}=$ Hasil belajar keterampilan membaca bahasa Arab siswa yang memperoleh pembelajaran dengan model pembelajaran Mind Mapping

$\mu_{A 2}=$ Hasil belajar keterampilan membaca bahasa Arab siswa yang memperoleh pembelajaran dengan model pembelajaran langsung

$\mu_{B 1}=$ Hasil belajar keterampilan membaca bahasa Arab siswa yang memiliki motivasi intrinsik tinggi

$\mu_{B 2}=$ Hasil belajar keterampilan membaca bahasa Arab siswa yang memiliki motivasi intrinsik rendah

A $\times$ B $=$ Interaksi antara model pembelajaran dengan motivasi intrinsik.

\section{HASIL PENELITIAN}

\section{A. Pengujian Hipotesis}

Sebelum melakukan pengujian hipotesis terlebih dahulu menghitung total skor dan rata-rata skor tiap perlakuan menggunakan teknik analisis varians dua jalur (ANAVA) faktorial $2 \times 2$, selanjutnya dapat digunakan sebagai dasar keputusan statistik untuk pengujian hipotesis, seperti pada Tabel 2 berikut. 
Tabel 2. Rangkuman Data Hasil Perhitungan Analisis Deskriptif

\begin{tabular}{|c|c|c|c|c|c|c|}
\hline \multirow{2}{*}{$\begin{array}{c}\text { Variabel } \\
\text { Tinggi }\end{array}$} & \multicolumn{2}{|c|}{ Mind Mapping } & \multicolumn{2}{|c|}{ Langsung } & \multicolumn{2}{|c|}{ Total } \\
\hline & $\mathbf{n}_{1}$ & 20 & $\mathbf{n}_{3}$ & 20 & $\mathbf{n}_{1,3}$ & 40 \\
\hline & $\bar{x}_{1}$ & 29,65 & $\overline{\mathbf{x}}_{3}$ & 24,40 & $\overline{\mathrm{x}}_{1,3}$ & 27,03 \\
\hline & $\mathrm{s}_{1}$ & 2,32 & $\mathbf{S}_{3}$ & 2,76 & $s_{1,3}$ & 2,42 \\
\hline \multirow[t]{3}{*}{ Rendah } & $\mathbf{n}_{2}$ & 20 & $\mathbf{n}_{4}$ & 20 & $n_{2}, 4$ & 40 \\
\hline & $\overline{\mathrm{x}}_{2}$ & 20,85 & $\overline{\mathrm{X}}_{4}$ & 22,80 & $\bar{x}_{2}, 4$ & 21,83 \\
\hline & $\mathrm{S}_{2}$ & 3,37 & $\mathrm{~S}_{4}$ & 2,28 & $s_{2}, 4$ & 2,81 \\
\hline \multirow{3}{*}{ Total } & $\mathrm{n}_{1}, 2$ & 40 & $n_{3}, 4$ & 40 & $\mathrm{~N}$ & 80 \\
\hline & $\overline{\mathrm{x}}_{1,2}$ & 25,25 & $\overline{\mathrm{x}}_{3}, 4$ & 23,60 & $\overline{\mathrm{x}}$ & 24,43 \\
\hline & $\mathrm{s}_{1,2}$ & 5,69 & $s_{3}, 4$ & 5,04 & $S$ & 2,62 \\
\hline
\end{tabular}

Secara keseluruhan hasil ANAVA 2 jalur factorial 2 x 2 untuk pengujian hipotesis dapat dilihat pada Tabel 3 berikut.

Tabel 3. Rangkuman Hasil Perhitungan ANAVA Faktorial 2 x 2

\begin{tabular}{lrrrrrr}
\hline \multicolumn{1}{c}{ Sumber Varians } & \multicolumn{1}{c}{ JK } & $\mathbf{d k}$ & \multicolumn{1}{c}{ RJK } & $\mathbf{F}_{\text {hì }}$ tung & $\mathbf{F}_{\text {tabel }}$ & Ket. \\
\hline Model Pembelajaran & 54,45 & 1 & 54,45 & 6,08 & 3,97 & Signifikan \\
\hline Motivasi Intrinsik & 540,80 & 1 & 540,80 & 60,34 & & Signifikan \\
\hline Interaksi & 259,20 & 1 & 259,20 & 28,92 & & Signifikan \\
\hline Galat & 681,10 & 76 & 8,96 & & & \\
\hline \multicolumn{1}{c}{$\quad$ Total } & 1535,55 & 79 & & & & \\
\hline
\end{tabular}

Perbedaan Hasil Belajar Keterampilan Membaca Antara Siswa yang Diajar dengan Model Pembelajaran Mind Mapping dan Langsung

Pengujian dilakukan terhadap hipotesis statistik untuk model pembelajaran mind mapping dan model pembelajaran langsung . yang dirumuskan sebagai berikut.

$$
\begin{aligned}
& H_{o}: \mu_{A 1}=\mu_{A 2} \\
& H_{a}: \mu_{A 1}>\mu_{A 2}
\end{aligned}
$$

Berdasarkan hasil pengujian hipotesis pada Tabel 3 di atas diperoleh hasil perhitungan data model pembelajaran, dimana $\mathbf{F}_{\text {hîtung }}=$ 6,08 , sementara nilai kritik $\mathbf{F}_{\text {tabel }}=$ dengan dk $(1,76)$ pada $\propto=0,05$ adalah sebesar 3,97. Hasil ini menunjukkan bahwa $\mathbf{F}_{\text {hĩtung }}=6,08>$ $\mathbf{F}_{\text {tabel }}=3,96$ sehingga Hipotesis $\mathrm{Nol}(\mathrm{Ho})$ ditolak, dan Hipotesis Alternatif (Ha) diterima, dengan demikian hipotesis penelitian yang menyatakan bahwa hasil belajar keterampilan membaca bahasa Arab siswa yang dibelajarkan dengan model pembelajaran mind mapping lebih tinggi dari pada siswa yang diajar dengan model pembelajaran langsung teruji kebenarannya.
Perbedaan Hasil Belajar Keterampilan Membaca Bahasa Arab Antara Siswa yang Memiliki Motivasi Intrinsik Tinggi dan Motivasi Intrinsik Rendah Adapun hipotesis statistic yang diuji adalah :

$$
\begin{aligned}
& H_{o}: \mu_{B 1}=\mu_{B 2} \\
& H_{a}: \mu_{B 1}>\mu_{B 2}
\end{aligned}
$$

Berdasarkan hasil pengujian hipotesis pada Tabel 25 di atas diperoleh hasil perhitungan data motivasi intrinsik, dimana $\mathbf{F}_{\text {hitung }=60,34 \text { dan nilai kritik }} \mathbf{F}_{\text {tabel dengan }}$ $\mathrm{dk}=1,76)$ pada $\propto$ $=0,05$ adalah 3,96. Hasil ini menunjukkan bahwa $\mathbf{F}_{\text {hìtung }}=60,34>\mathbf{F}_{\text {tabel }}$ $=3,97$ sehingga Hipotesis Nol (Ho) ditolak dan Hipotesis Alternatif (Ha) diterima, dengan demikian hipotesis penelitian yang menyatakan bahwa siswa yang memiliki motivasi intrinsik tinggi memperoleh hasil belajar keterampilan membaca bahasa Arab yang lebih tinggi dari pada siswa yang memiliki motivasi intrinsik rendah teruji kebenarannya.

Interaksi Antara Model Pembelajaran dan Motivasi Intrinsik Siswa Terhadap Hasil Belajar Keterampilan Membaca Bahasa Arab 
Adapun hipotesis statistik yang diuji adalah :

Ho : $\mathrm{A} \times \mathrm{B}=0$

$\mathrm{Ha}: \mathrm{A} \times \mathrm{B} \neq 0$

Berdasarkan hasil pengujian hipotesis di atas diperoleh perhitungan interaksi model pembelajaran dengan motivasi intrinsik, dimana $\mathbf{F}_{\text {hítung }}=28,92$ dan nilai kritik $\mathbf{F}_{\text {tabel dengan }}$ $\mathrm{dk}=(1,76)$ pada pada $\propto=0,05$ adalah 3,97. Hasil ini menunjukkan bahwa $\mathbf{F}_{\text {hĩtung }}=28,92$ $>\mathbf{F}_{\text {tabel }}=3,96$ sehingga Hipotesis $\mathrm{Nol}(\mathrm{Ho})$ ditolak, dan Hipotesis Alternatif ( $\mathrm{Ha}$ ) diterima dengan demikian hipotesis penelitian yang menyatakan bahwa terdapat interaksi antara model pembelajaran dan motivasi intrinsik dalam memberikan pengaruh terhadap hasil belajar keterampilan membaca bahasa Arab teruji kebenarannya.

Karena ada interaksi antara model pembelajaran dan motivasi intrinsik terhadap hasil belajar keterampilan membaca bahasa Arab, maka perlu dilakukan uji lanjutan (post hoc test), untuk mengetahui rata-rata hasil belajar keterampilan membaca sampel mana yang berbeda. Untuk melihat bentuk interaksi antara model pembelajaran dan motivasi intrinsik dalam mempengaruhi hasil belajar keterampilan membaca bahasa Arab, dilakukan uji lanjut dengan menggunakan uji Tuckey.

Dari hasil uji Tuckey dapat dilihat bahwa terdapat 6 (enam) pasang hipotesis statistik, yakni :

a. Dari hasil perhitungan dengan menggunakan uji Tuckey pada Tabel di atas menunjukkan bahwa $\mathbf{F}_{\text {hîtung }}=7,84>\mathbf{F}_{\text {tabel }}=3,97$, sehingga memberikan keputusan menolak Ho. Dengan demikian, hipotesis penelitian yang menyatakan bahwa hasil belajar keterampilan membaca bahasa Arab siswa jika diajar dengan menggunakan model pembelajaran mind mapping lebih tinggi dibandingkan dengan model pembelajaran langsung untuk siswa yang memiliki motivasi intrinsik tinggi teruji kebenarannya.

b. Dari hasil perhitungan dengan menggunakan uji Tuckey pada Tabel di atas menunjukkan bahwa $\mathbf{F}_{\text {hìtung }}=13,15>\mathbf{F}_{\text {tabel }}=3,97$, sehingga memberikan keputusan menolak Ho. Dengan demikian, hipotesis penelitian yang menyatakan bahwa hasil belajar keterampilan membaca bahasa Arab siswa yang memiliki motivasi intrinsik tinggi jika diajar dengan model pembelajaran mind mapping lebih tinggi dari pada hasi belajar keterampilan membaca bahasa Arab siswa yang memiliki motivasi intrinsik rendah jika diajarkan dengan model pembelajaran langsung teruji kebenarannya.

c. Dari hasil perhitungan dengan menggunakan uji Tuckey pada Tabel di atas menunjukkan bahwa $\mathbf{F}_{\text {hitung }}=10,23>\mathbf{F}_{\text {tabel }}=3,97$, sehingga memberikan keputusan menolak Ho. Dengan demikian, hipotesis penelitian yang menyatakan bahwa hasil belajar keterampilan membaca bahasa Arab siswa yang memiliki motivasi intrinsik tinggi jika diajar dengan model pembelajaran mind mapping lebih tinggi dibandingkan dengan siswa yang memiliki motivasi intrinsik rendah teruji kebenarannya.

d. Dari hasil perhitungan dengan menggunakan uji Tuckey pada Tabel di atas menunjukkan bahwa $\mathbf{F}_{\text {hitung }}=5,30>\mathbf{F}_{\text {tabel }}=3,97$, sehingga memberikan keputusan menolak Ho. Dengan demikian, hipotesis penelitian yang menyatakan bahwa hasil belajar keterampilan membaca bahasa Arab siswa yang memiliki motivasi intrinsik tinggi jika diajar dengan model pembelajaran langsung lebih tinggi dari pada hasil belajar keterampilan membaca bahasa Arab siswa yang memiliki motivasi intrinsik rendah jika diajar dengan model pembelajaran mind mapping teruji kebenarannya.

e. Dari hasil perhitungan dengan menggunakan uji Tuckey pada Tabel di atas menunjukkan bahwa $\mathbf{F}_{\text {hitung }}=4,30>\mathbf{F}_{\text {tabel }}=3,97$, sehingga memberikan keputusan menolak Ho. Dengan demikian, hipotesis penelitian yang menyatakan bahwa hasil belajar keterampilan membaca bahasa Arab siswa yang memiliki motivasi intrinsik tinggi jika diajar dengan model pembelajaran langsung lebih tinggi dari pada hasil belajar keterampilan membaca bahasa Arab siswa yang memiliki motivasi intrinsik rendah jika diajar dengan model pembelajaran lansung teruji kebenarannya.

f. Dari hasil perhitungan dengan menggunakan uji Tuckey pada Tabel di atas menunjukkan bahwa $\mathbf{F}_{\text {hitung }}=4,02>\mathbf{F}_{\text {tabel }}=3,97$, sehingga memberikan keputusan menolak Ho. Dengan demikian, hipotesis penelitian yang menyatakan bahwa hasil belajar keterampilan membaca bahasa Arab siswa yang memiliki motivasi intrinsik rendah jika 
g. diajar dengan model pembelajaran langsung lebih tinggi dari pada hasil belajar keterampilan membaca bahasa Arab siswa yang memiliki motivasi intrinsik rendah jika diajar dengan model pembelajaran mind mapping teruji kebenarannya.
Selanjutnya adanya interaksi antara variabel model pembelajaran dan motivasi intrinsik terhadap hasil belajar keterampilan membaca bahasa Arab siswa, maka perlu diberikan gambaran grafik estimasi yang menunjukkan adanya interaksi tersebut.

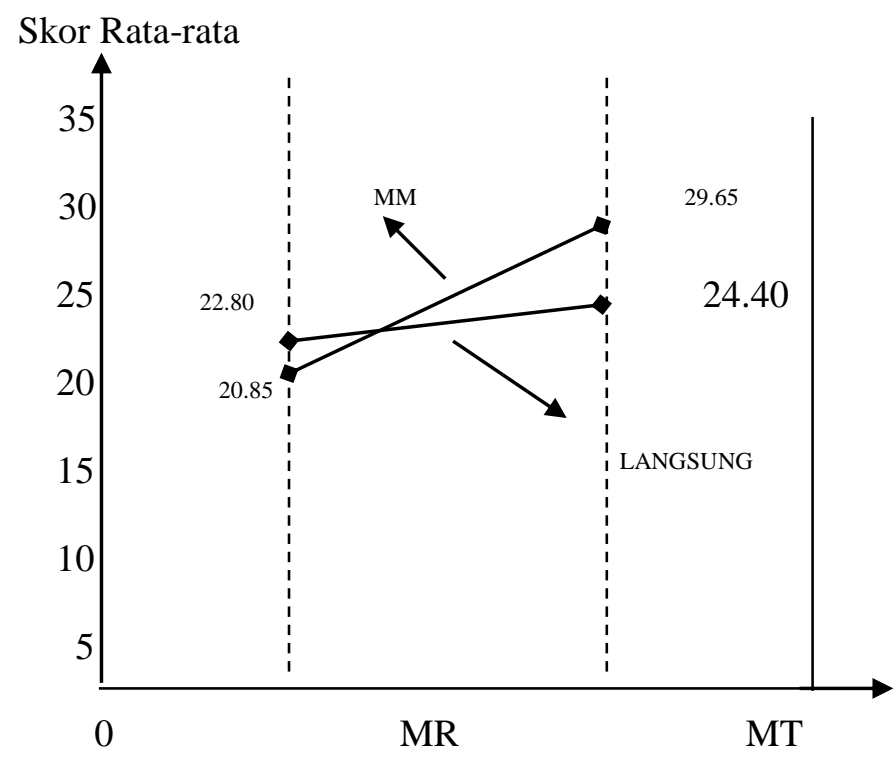

Motivasi Intrinsik

\section{PEMBAHASAN}

Pebedaan Hasil Belajar Keterampilan Membaca Bahasa Arab Siswa yang Diajar dengan Model Pembelajaran Mind Mapping dan Model Pembelajaran Langsung.

Hasil penelitian ini telah menunjukkan bahwa hasil belajar keterampilan membaca bahasa Arab siswa yang diajar dengan model pembelajaran mind mapping lebih tinggi dibandingkan dengan model pembelajaran langsung. Kenyataan ini membuktikan bahwa model pembelajaran mind mapping lebih baik dalam meningkatkan keterampilan membaca siswa dalam pembelajaran bahasa Arab daripada penggunaan model pembelajaran langsung. Keterampilan membaca bahasa Arab merupakan kegiatan pembelajaran untuk mampu membaca bahasa Arab yang baik dan benar sesuai dengan kaidah-kaidah yang berlaku dalam bahasa Arab secara tematis. Selain itu keterampilan membaca bahasa Arab bertujuan agar siswa dapat memahami AlQur'an dan Hadits sebagai sumber hukum dan ajaran Islam, agar siswa dapat memahami dan mengerti buku-buku agama dan kebudayaan Islam yang ditulis dalam bahasa Arab, agar siswa dapat berbicara dan mengarang bahasa
Arab, agar siswa dapat menggunakannya sebagai alat pembantu dalam keahlian lainnya, dan agar siswa dapat menjadi ahli bahasa Arab yang professional. Untuk itu, guru diharapkan memiliki pengetahuan dan pemahaman mengenai model pembelajaran, sebab pengetahuan dan pemahaman model pembelajaran sangat penting sebagai salah satu upaya dalam memberikan pengalaman dan pencapaian tujuan belajar yang optimal guru dituntut untuk meningkatkan mutu pembelajaran dan harus memperhatikan hakikat, tujuan mata pelajaran yang akan diajarkan, serta mempertimbangkan karakteristik siswa.

Hal di atas sesuai dengan pendapat Purwanto (2007) bahwa dalam belajar di sekolah, faktor guru dan cara mengajarnya merupakan faktor yang sangat penting. Artinya, penguasaan guru terhadap model pembelajaran sangat diperlukan dalam meningkatkan kemampuan profesional guru dalam mengajar, oleh sebab itu guru harus dapat menentukan model yang paling tepat dan sesuai dengan tujuan serta materi yang akan disampaikannya.

Dalam model pembelajaran mind mapping, siswalah yang memegang peranan penting, siswa harus berpikir sendiri mencari 
jawawaban atas apa masalah yang dihadapinya. Model mind mapping ditujukan untuk memperoleh hasil belajar keterampilan membaca yang lebih baik, sehingga pengetahuan itu akan lebih bertahan lama dan mudah untuk diingat dibandingkan pengetahuan yang diperoleh dari model-model lain. Pada model ini hasil belajar keterampilan membaca lebih baik dan tidak kalah pentingnya secara menyeluruh model pembelajaran mind mapping dapat meningkatkan kreatifitas dan kemampuan berpikir bebas, secara khusus belajar melatih keterampilan-keterampilan kognitif dengan menggambarkan dan menggabungkan kata-kata menjadi kalimat bacaan yang ditandai dengan warna-warni. Dengan begitu, pengetahuan dan keterampilan membaca siswa bertahan lama karena siswa yang menyusun wacana bacaannya sendiri, sedangkan guru hanya sebagai fasilitator dan pengontrol kegiatan belajar siswa.

Selanjutnya Dick, Carey dan Carcy (2005) mengemukakan bahwa model pembelajaran langsung cenderung menggunakan hapalan-hapalan dan lebih mengarah ke aspek memorization, yang menitik beratkan unsur ingatan, sehingga siswa memperoleh pengetahuan dan keterampilan membaca dengan cara menghubungkan katakata dengan subjek secara berulang-ulang, yang pada akhirnya bila siswa belum hapal dengan sempurna, maka materi tersebut tidak dapat diteruskan atau ditambah. Dalam model pengorganisasian ini, guru yang lebih banyak berperan, artinya siswa tidak terlibat secara langsung dalalm materi dan menemukan materi-materi penting dari suatu proses pembelajaran, sehingga pengetahuan dan keterampilan membaca yang diperoleh tidak mampu meningkatkan retensi dan daya ingat siswa, atau hanya berada dalam memori ingatan jangka pendek saja. Akhirnya, keberhasilan siswa dalam belajar amat tergantung pada penyampaian guru, kemampuan, dan pengalaman guru saja. Pembelajaran seperti ini akan berpotensi untuk memberikan perolehan hasil belajar keterampilan membaca yang kurang maksimal. Model pembelajaran langsung tidak mendorong tumbuhnya rasa keingintahuan dan rasa tanggung jawab siswa dalam merencanakan dan mengorganisasikan cara belajarnya. Akibatnya, pengetahuan dan keterampilan membaca yang dimiliki siswa hanya berada pada ingatan jangka pendek saja, dan akan cenderung tidak mampu dalam meningkatkan daya retensi siswa terhadap materi pelajarannya. Dalam pembelajaran tersebut komunikasi yang berlangsung dalam proses pembelajaran satu arah, maka cenderung menimbulkan kesalahpahaman siswa terhadap konsep-konsep dan istilah tertentu.

Dari uraian di atas, dapat dipahami bahwa hasil belajar keterampilan membaca bahasa Arab siswa yang diajar dengan model pembelajaran mind mapping lebih baik dari pada siswa yang dibelajarkan dengan model pembelajaran langsung hal ini mendukung penelitian sebelumnya yang dilakukan oleh Hendra Sihotang (2009), menyimpulkan bahwa hasil belajar membaca bahasa Indonesia siswa yang diajar dengan model pembelajaran mind mapping lebih baik daripada kelompok siswa yang mengikuti pembelajaran ekspositori. Hasil penelitian Meri Rosmida Panjaitan (2011), menyimpulkan bahwa hasil belajar kosakata bahasa Inggris siswa yang diajar dengan model pembelajaran mind mapping lebih tinggi daripada hasil belajar siswa yang diajar dengan model pembelajaran langsung.

Perbedaan Hasil Belajar Keterampilan Membaca Bahasa Arab Antara Siswa yang Memiliki Motivasi Intrinsik Tinggi dengan Siswa yang Memiliki Motivasi Intrinsik Rendah Hasil penelitian ini telah menunjukkan bahwa siswa yang memiliki mmotivasi intrinsik tinggi memperoleh nilai rata-rata hasil belajar keterampilan membaca bahasa Arab yang lebih baik dibandingkan dengan siswa yang memiliki motivasi intrinsik rendah. Motivasi intrinsik merupakan motivasi yang berasal dari dalam diri individu yang bersangkutan. Terdapat lima aspek dalam motivasi intrinsik, yaitu (1) rasa ingin tahu yang mendorong seseorang untuk mengetahui hal-hal yang ada di lingkungannya, (2) mempunyai inisiatif belajar untuk memuaskan diri sendiri (indepedent judgement) merupakan keputusan atau penelitian mandiri yang mendorong individu untuk membuat keputusan sendiri dalam memecahkan masalah, (3) memilih pekerjaan yang menantang, kompleks, baru, dan sulit diramalkan (challenge) aspek ini menandakan adanya suatu dorongan untuk mengatasi suatu masalah yang menantang, sukar, dan rumit, (4) mempunyai keinginan bekerja secara mandiri (mastery) aspek ini menandakan adanya suatu dorongan dalam diri individu untuk dapat menguasai diri dan lingkungan, (5) memiliki kriteria internal untuk 
menentukan sukses atau gagal (internal criteria) kriteria yang dimaksud adalah semacam pedoman penilaian mengenai kesuksesan dan kegagalan yang dialami seseorang.

Menurut Santrock (2000), sebenarnya lebih baik menerapkan motivasi intrinsik dalam memahami pelajaran. Karena dengan memberikan kebebasan kepada siswa untuk memilih sesuatu yang disukai agar selama proses pembelajaran siswa dapat melakukannya dengan senang hati dan hasil belajar yang didapatkan adalah positif. Namun tetap diberikan bimbingan dan didorong untuk mampu bertanggung jawab atas tindakan dan pilihan siswa.

Siswa yang memiliki motivasi intrinsik tinggi lebih mampu memanfaatkan sumber belajar yang ada secara maksimal untuk mempercepat proses keterampilan membaca bahasa Arab, yang pada gilirannya motivasi intrinsik siswa juga akan memiliki pengaruh yang berarti terhadap peningkatan prestasi belajar keterampilan membaca siswa. Oleh karena itu apabila siswa yang memiliki motivasi intrinsik tinggi maka siswa itu diduga akan mempunyai prestasi keterampilan membaca yang lebih baik dalam belajar. Sedangkan siswa yang memiliki motivasi intrinsik rendah kurang mampu memanfaatkan sumber balajar yang ada dan tidak mampu untuk belajar lebih kreatif dan efektif dalam memecahkan masalah, sehingga dengan motivasi intrinsik yang rendah juga akan mempengaruhi peningkatan prestasi keterampilan membaca siswa yang relatif lebih rendah. Oleh karena itu apabila siswa memiliki motivasi intrinsik rendah maka siswa itu diduga akan mempunyai prestasi yang rendah.

Dari uraian di atas, dapat dipahami bahwa mata pelajaran bahasa Arab mempunyai peranan penting dalam membantu siswa mengaplikasikan ilmu dalam pemenuhan kebutuhan hidupnya. Hal tersebut dapat dilakukan dengan menganalisis segala kegiatan membaca bahasa Arab yang mampu meningkatkan membaca kitab-kitab yang bertuliskan bahasa Arab baik al-Qur'an dan Hadits. Dengan demikian, untuk memahami keterampilan membaca bahasa Arab tersebut, semua pengetahuan dan keterampilan harus dirangkai dalam suatu sistem yang saling berhubungan. Dengan demikian, untuk memahami bacaan materi bahasa Arab tersebut dengan baik, dan untuk merangkai materimateri pelajaran tersebut agar saling berhubungan, seorang siswa harus memiliki motivasi intrinsik tinggi, rasa ingin tahu, dan intelektual agar mampu memahami bacaan materi dengan baik. Motivasi intrinsik tinggi dalam diri siswa, akan memberikan peluang kepada siswa tersebut untuk menguasai dan memahami dengan cepat materi pelajaran yang disiapkan.

Sedangkan siswa yang memiliki motivasi intrinsik rendah memiliki kerampilan yang kurang berbuat lebih baik dibandingkan dengan siswa yang memiliki motivasi intrinsik tinggi. Siswa yang memiliki motivasi intrinsik rendah cenderung kurang mampu untuk menelaah bacaan dan mempelajari lebih mendalam bacaan bahasa Arab yang artinya siswa tersebut tidak memiliki keinginan dari dalam dirinya untuk berprestasi dari murid yang lainnya. Sementara dalam mempelajari bacaan bahasa Arab lebih dituntut adanya suatu hasrat atau keinginan dari dalam dirinya untuk berusaha, mencoba dan mencari lebih mendetail lagi hal apa saja yang memungkinkan untuk meningkatkan keterampilan membaca bahasa Arab. Sementara siswa yang memiliki motivasi intrinsik rendah tidak memiliki ciri tuntutan tersebut, hal itu akan membawa akibat yang memungkinkan siswa tidak berusaha dan tidak aktif dalam belajar karena tidak ada dorongan dalam dirinya untuk mencapai suatu keberhasilan. Siswa yang memiliki motivasi intrinsik rendah tidak banyak berbuat atau kurang respon dalam mempelajari materi-materi bacaan bahasa arab sehingga pada gilirannya hasil belajar keterampilan membacanya kurang maksimal.

Berdasarkan uraian di atas, dapat dipahami bahwa siswa yang memiliki motivasi intrinsik tinggi memperoleh hasil belajar keterampilan membaca yang lebih tinggi dibandingkan dengan siswa yang memiliki motivasi intrinsik rendah. Hasil penelitian ini didukung oleh penelitian sebelumnya yang dikemukakan oleh Handoko (2009) yang menyimpulkan bahwa siswa yang memiliki motivasi intrinsik tinggi memperoleh hasil belajar lebih tinggi dari siswa yang memiliki motivasi intrinsik rendah. Selanjutnya Lisnawati (2008) menyatakan bahwa terdapat perbedaan hasil belajar membaca antara siswa yang memiliki motivasi intrinsik tinggi yang dibelajarkan dengan metode membaca SQ3R dengan hasil belajar membaca siswa yang memiliki motivasi intrinsik rendah pada mata pelajaran Sosiologi. 
Interaksi Antara Model Pembelajaran Dan Motivasi Intrinsik Dalam Mempengaruhi Hasi Belajar Keterampilan Membaca Bahasa Arab Siswa

Hasil penelitian ini menunjukkan bahwa terdapat interaksi antara model pembelajaran dan motivasi intrinsik dalam mempengaruhi hasil belajar keterampilan membaca bahasa Arab siswa. Siswa yang memiliki motivasi intrinsik tinggi dengan mengikuti model pembelajaran mind mapping lebih tinggi hasil belajarnya dibandingkan dengan siswa yang memiliki motivasi intrinsik rendah dengan model pembelajaran mind mapping. Demikian pula siswa yang memiliki motivasi intrinsik rendah dengan mengikuti model pembelajaran langsung memperoleh hasil belajar keterampilan membaca bahasa Arab lebih tinggi dibandingkan dengan siswa yang memiliki motivasi intrinsik tinggi dengan model pembelajaran langsung. Keterampilan membaca bahasa Arab merupakan kompetensi yang harus dimilliki oleh siswa dalam memahami bahasa Arab. Jika keterampilan membaca siswa tinggi, maka siswa dapat memahami mata pelajaran bahasa Arab dengan mudah dan kitab-kitab yang bertuliskan bahasa Arab, karena membaca merupakan kegiatan pembelajaran yang sangat sulit bagi siswa. Keterampilan membaca sangat berpengaruh terhadap keteramppilan lainnya, jika siswa sulit dalam membaca bahasa Arab maka siswa akan sulit dalam menulis, berbicara, dan mendengarkan. Keterampilan ini akan lebih mudah diperoleh oleh siswa yang memiliki motivasi intrinsik tinggi yang cenderung aktif dan kreatif dari dalam dirinya dalam memahami bacaan bahasa Arab. Sikap ini akan lebih berkembang jika siswa aktif belajar secara mandiri dengan mengaktifkan otak kiri dan otak kanannnya sesuai dengan metode pembelajaran yang ada. Untuk siswa yang memiliki motivasi intrinsik rendah, pembelajaran keterampilan membaca bahasa Arab lebih baik jika diajar dengan model pembelajaran langsung. Hal ini mungkin disebabkan karena model pembelajaran langsung cenderung menggunakan langkah-langkah ilmiah atau konsep ilmiah yang telah ditetapkan oleh guru dan lebih berpengaruh ke aspek ingatan dan pemahaman yang langsung yang dirasakan oleh siswa yang memiliki motivasi intrinsik rendah.

Meskipun model pembelajaran mind mapping baik digunakan pada siswa yang memiliki motivasi intrinsik tinggi, namun ridak tertutup kemungkinan model pembelajaran mind mapping ini juga dapat digunakan pada siswa yang memiliki motivasi intrinsik rendah. Hal ini dikarenakan kreatifitas dalam memecahkan masalah yang muncul melatih siswa untuk meningkatkan kemauan dalam diri siswa dan sehingga mampu memotivasi siswa dalam menggeluti keterampilan membaca bahasa Arab sesuai dengan kompetensi yang diharapkan dari mata pelajaran bahasa Arab, khususnya pada siswa SMP.

Berdasarkan hasil penelitian yang menunjukkan adanya interaksi antara model pembelajaran dengan motivasi intrinsik terhadap hasil belajar keterampilan membaca, maka hasil penelitian ini juga mendukung penelitian sebelumnyayang dilakukan oleh Meri Rosmida Panjaitan (2011) yang dalam penelitiannya menyimpulkan bahwa terdapat interaksi antara model pembelajaran dan motivasi intrinsik terhadap hasil belajar keterampilan membaca bahasa Inggris, artinya bahwa interaksi model pembelajaran dan motivasi intrinsik memberikan pengaruh terhadap bahasa Inggris secara signifikan.

Berdasarkan hasil belajar

keterampilan membaca siswa secara keseluruhan, terjadi peningkatan rata-rata hasil belajar keterampilan membaca siswa sebelum dan sesudah perlakuan, khususnya pada kelas perlakuan dengan model pembelajaran mind mapping. Sedangkan pada kelas perlakuan dengan model pembelajaran langsung, meski terjadi peningkatan rata-rata hasil belajar, namun peningkatan rata-rata hasil belajar keterampilan membaca ini tidak jauh berbeda jika dibandingkan dari rata-rata hasil pembelajaran yang selama ini dilaksanakan di lokasi penelitian sebelum penelitian dilaksanakan. Jika sebelum perlakuan pada kelas model pembelajaran mind mapping maupun kelas langsung nilai rata-rata harian siswa dalam setiap kali pertemuan hanya berkisar 60 sampai 70, namun setelah dilaksanakan perlakuan terjadi peningkatan hasil belajar keterampilan membaca rata-rata siswa antara 75 sampai 90.

\section{PENUTUP}

Berdasarkan hasil penelitian dan pembahasan yang dikemukakan sebelumnya, maka dapat simpulkan bahwa :

1. Hasil belajar keterampilan membaca bahasa Arab siswa dengan model pembelajaran 
mind mapping lebih baik dibandingkan dengan model pembelajaran langsung. Dalam hal ini hasil belajar keterampilan membaca bahasa Arab siswa yang dibelajarkan dengan menggunakan model pembelajaran mind mapping lebih tinggi dibandingkan dengan hasil belajar keterampilan membaca bahasa Arab siswa yang dibelajarkan dengan model pembelajaran langsung.

2. Hasil belajar keterampilan membaca bahasa Arab siswa yang memiliki motivasi intrinsik tinggi lebih baik dibandingkan dengan hasil belajar keterampilan membaca bahasa Arab siswa yang memiliki motivasi intrinsik rendah. Dengan demikian siswa yang memiliki motivasi intrinsik tinggi memperoleh hasil belajar keterampilan membaca bahasa Arab yang lebih tinggi dibandingkan dengan siswa yang memiliki motivasi intrinsik rendah.

3. Terdapat interaksi antara model pembelajaran dan motivasi intrinsik dalam mempengaruhi hasil belajar keterampilan membaca bahasa Arab. Untuk siswa yang memiliki motivasi intrinsik tinggi lebih efektif dalam meningkatkan hasil belajar keterampilan membaca bahasa Arab jika dibelajarkan menggunakan model pembelajaran mind mapping, sedangkan untuk siswa yang memiliki motivasi intrinsik rendah lebih efektif dalam meningkatkan hasil belajar keterampilan membaca bahasa Arab bila dibelajarkan dengan menggunakan model pembelajaran langsung.

\section{DAFTAR PUSTAKA}

Al Ghazali. 2005. Pedoman Pengajaran Bahasa Arab di Perguruan Tinggi. Jakarta : GIP

Arends, Richardl. 1997. Classroom Instructional Management. New York : The McGraw Hill Company

Arends. 2001. Learning to Teach. Yogyakarta : Pustaka Belajar

Arikunto, S. 2002. Dasar-dasar Evaluasi Pendidikan. Jakarta: Pustaka Pelajar

Bloom, B.S. 1985. Taxonomy of Educational Objectives. Handbook 1 : Cognitive domain. New York : David Mckay

Burns, PC., Betty, D, dan Ross, EP. 1996. Teaching Reading in Today's Elementary Schools. Chicago : Rand Mc. Nally College Publishing
Buzan, Tony. 2001. Mind Map Untuk Meningkatkan Kreativitas. Jakarta : PT. Gramedia Pustaka Utama

Buzan, Tony. 2004. Memahami Peta Pikiran. Batam : Interaksa

Crawley, SJ. dan Mountain, L. (1995). Strategies for Guiding Content Reading. Boston : Allyn and Bacon

Departemen Agama. 2003. Kurikulum Berbasis Kompetensi dan Hasil Belajar untuk Madrasah Tsanawiyah. Jakarta : Dirjen Kelembagaan Agama Islam Depag

DePorter. 2002. Quantum Learning: Membiasakan Belajar Nyaman dan Menyenangkan. Bandung : Kaifa

DePorter dan Mike. 2005. Quantum learning. Penerjemah alwiyah abdurrahman

Dick, W. and Carey, L, Carcy. 2005. The Systematic Design of Instruction. Fourth Edition. New York: Harper Colins College Publisher

Djamarah S , Arwan, Z. 2002. Strategi Belajar Mengajar. Jakarta : Rineka

Gagne. 1984. Principles of Instructional Design. Second Edition. New York : Holt Rinehart and Winston

Gulo, W. 2008. Strategi Belajar Mengajar. Jakarta : Grasindo

Herter. 1981. Psikologi Belajar. Jakarta. Renika Cipta

Joyce B, dan Weil, M. 1992. Models of Teaching (4th ed.) Englewood Cliffs, N. $\mathrm{J}$ : Prentice Hall

Kardi, S dan Nur, M. 2000. Pengajaran Langsung. Surabaya : University Press

Klien, ML, Peterson, S, dan Semingston, L. 1996. Teaching Reading in the Elementary Grades. Boston : Allyn and Bacon

Louwis, M. 1991. Al-Munjid Fil Al-Alugan A'lam. Beirut : Daral Masrig

Maslow, A. H. 1983. A Theory of Human Motivation. Psychological Review.

McLoughlin, M, dan Allen, M.B. 2002. Guided Comprehension. Newark : International Reading Association

McClelland. 1975. The Achievement Motive. New York : Irvington, Inc.

Pangkalan Ide. 2009. Menyeimbangkan Otak Kiri dan Otak Kanan. Jakarta : PT. elex media komputindo

Piaget, J. 1972. The Principles of Genetic Epistemology. New York. Basic Books

Shakholid. 2005. Analisis Kontrastif Bahasa Arab dan Bahasa Indonesia. Jakarta 
Slameto. 2003. Belajar dan Faktor-faktor yang Mempengaruhi. Jakarta : Rineka Cipta

Sudjana. 2002. Metode Statistika. Bandung : Tarsito

Syafei, I. 1999. Terampil Berbahasa Indonesia $I$ : Petunjuk Guru Bahasa Indonesia SMU Kelas I. Jakarta : Depdikbud

Trianto. 2007. Model-Model Pembelajaran Inovatif Berorientasi Konstruktivistik. Jakarta : Prestasi Pustaka

Yusuf, T. dan Anwar, S. 1995. Metodologi Pengajaran Agama dan Bahasa Arab. Jakarta : Hidakarya Agung

Winataputra, H.U.S. 2001. Strategi Belajar Mengajar. Jakarta : PPUT

Windura. 2008. Mind Map Langkah demi Langkah. Jakarta : PT. Elex media komputindo 